\title{
動燃事業団におけるプルトニウム燃料開発施設
}

\author{
(1972年 1 月 17 日 受理) \\ Plutonium Fuel Development Laboratory of Power Reactor
and Nuclear Fuel Development Corporation
}

鈴 木 進*

By Susumu SUZUKI

The Second Plutonium Fuel Development Laboratory of the Power Reactor and Nuclear Fuel Development Corporation, which had been under construction since 1969. has now been completed, and production of Pu fuels for both FBR and ATR commenced in Feb. 1972. The total floor space is about $9,000 \mathrm{~m}^{2}$ in which are housed separate production lines for FBR and ATR (pellet preparation, pin fabrication, assembling and recovery), as well as facilities for quality control fuel storage, air conditioning and management office. The annual production capacity is $5 t$ and $3 t$ for ATR and FBR, respectively. Some of the production facilities were equipped to operate automatically in order to reduce the risk of human radiation exposure. Systems for criticality control and material balance are described together with an outline of the arrangement of the facilities with fully equipped alarm system.

動力炉. 核燃料開発事業団東海事業所の Pu 燃料第

1 開発室は1966年 1 月から 5 年有余稼動実績を示し, この間の操業は順調に進み施設運転の安全性も確認さ れ, 燃料製造技術開発, 炬外評価試験, 照射試験を通し ての燃料举動解析, 燃料設計評仙等々に多くの成果得 ることができた。今般さらに高速增殖炉実験炬および 新型転換炉原型炉の開発に関連して燃料製造施設とし て $\mathrm{Pu}$ 燃料第 2 開発室が建設され，72年早々 $\mathrm{Pu}$ 取 り扱っての操業を開始するので，その施設を紹介す る。

\section{I . 施設建設経過}

$\mathrm{Pu}$ 燃料第 2 開発室の建家, 付帯施設, 内装機器の設 計は, 1968年に開始され69年から建設が始められたが, 施設は高速增殖炉用燃料製造施設(以下 FBRラインと 称する)之新型転換炉用燃料製造施設(以下 ATR ライ ンと称する)の 2 つた大別して建設を進めた。その経 過怔第 1 表に略示する。

\section{II. 施 設 概 要}

建家は 2 階建鉄筋コンクリート耐火耐震構造で，地 下施設はなく1階はPu燃料製造の(1)主工程(ペレット 製造, ピン充填加工, 果合体組立)，(2)回収工程(乾式回 収, 湿式回収括上び廃液処理)，(3)品質管理工程(分析和 よび物性測定)，(4)貯蔵(原料製品および回収品)，(5)製 造作業等注にわる現昜管理, 放射線管理,緊急除染, 更衣休憩室等の場所に当られている。

2 階は(1)給排気施設ならびに中央監視施設, (2)スタ $ッ>$ 室, 会議室K, 一部中 2 階飞物質移動計量管理制御 およびデータ集積を行う計算機室が設けられた。

総床面積は 1 階 $4,873 \mathrm{~m}^{2}, 2$ 階 $3,856 \mathrm{~m}^{2}$, 中 2 階 $248 \mathrm{~m}^{2}$,

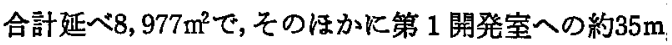

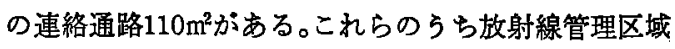
として指定される約80\%の所は, 負圧維持が必要で気 密構造に保たれている。第 1,2 図汇 1 階, 2 階, 中 2 階

* 動力炻・核燃料開発事業団(Power Reactor \& Nucl. Fuel Develop. Corp.) 
第 1 表 $\mathrm{Pu}$ 燃料第 2 開発室建設経過

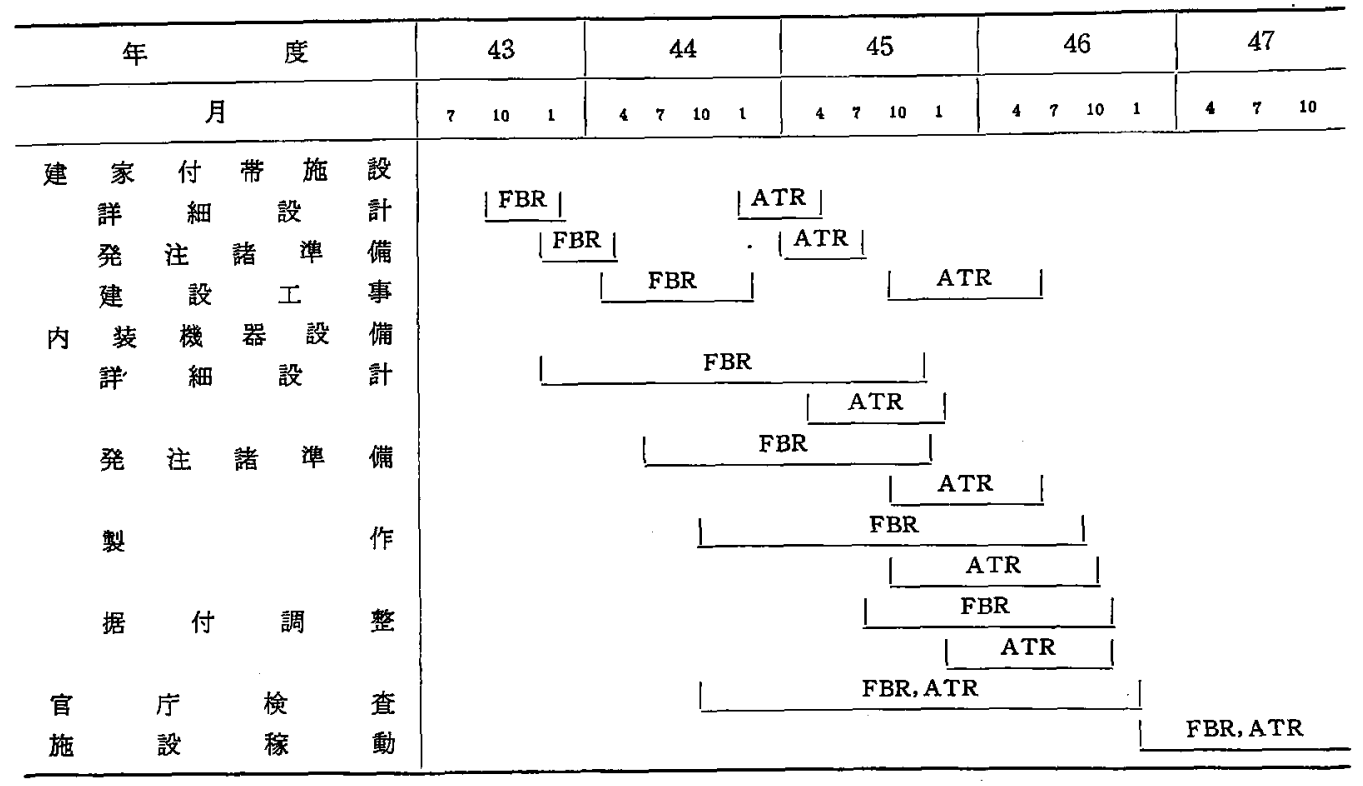

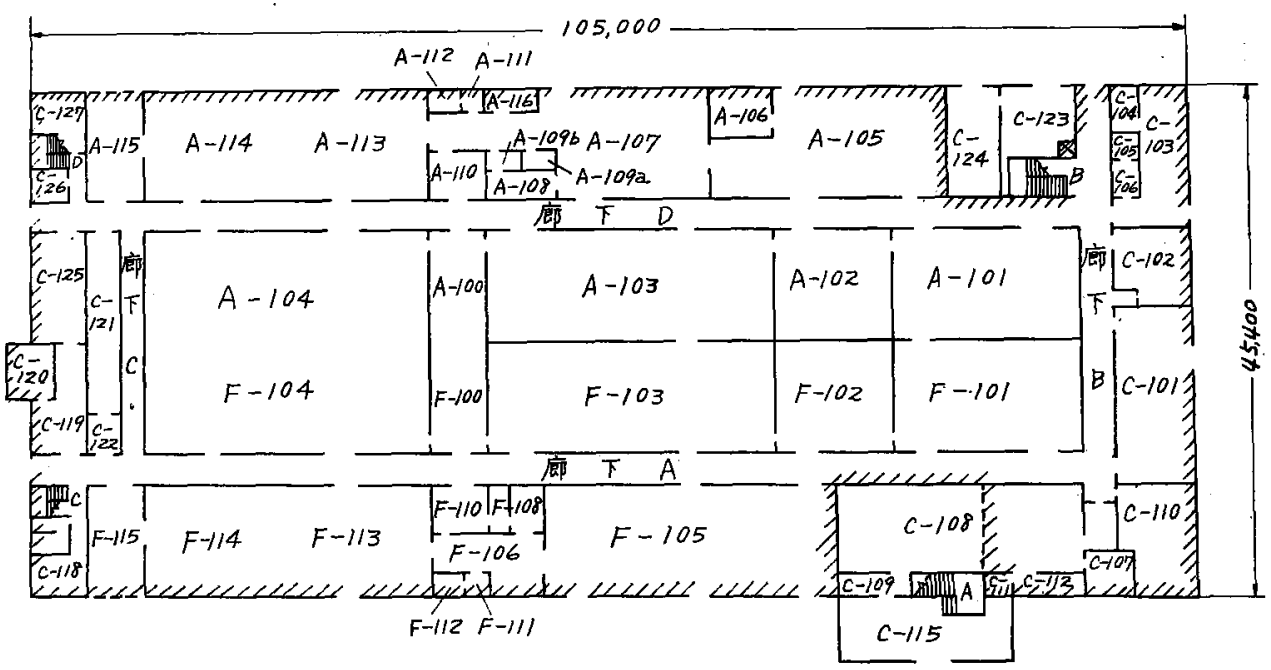
A: ATRライン
A-105 A-114 ATR組立工程
F: FBRライン
F-105 F-114 FBR組立工程
C: 共通ライン
C-101 C-04 分析物性工程
A-101 A-103 ATR乾式工程
F-101 F-103 FBR乾式工程
$\mathrm{C}-121 \sim \mathrm{C}-125$ 燃料䠉蔵等
A-104 湿式工程
F-104 湿式工程
C-110 RMO

\section{第 1 図 1 階平面図}

の平面図を示し，以下主要設備について概説する。

1. クローフボックス(GB)

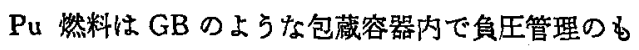
とで取り扱われるが，GB の本体部分はステンレス鋼. でネオブレン製グローブ付きのアクリル樹脂空板が取 り付けられている。核物筫の移動を GB の天井に付設
したホイストで行うため, 高さ2. 5〜2m, 横 6〜 $4 \mathrm{~m}$, 奥行 $1 \mathrm{~m}$ と非常に大きく高いGBを用いた。その配居 をオープンポートボックス,フードと共に第 3 图に示 す。GB 間で核物質を移動する場合は，FBR および

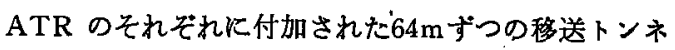
ルを用いる。GBには給排気ロにアブンリュートフィ 


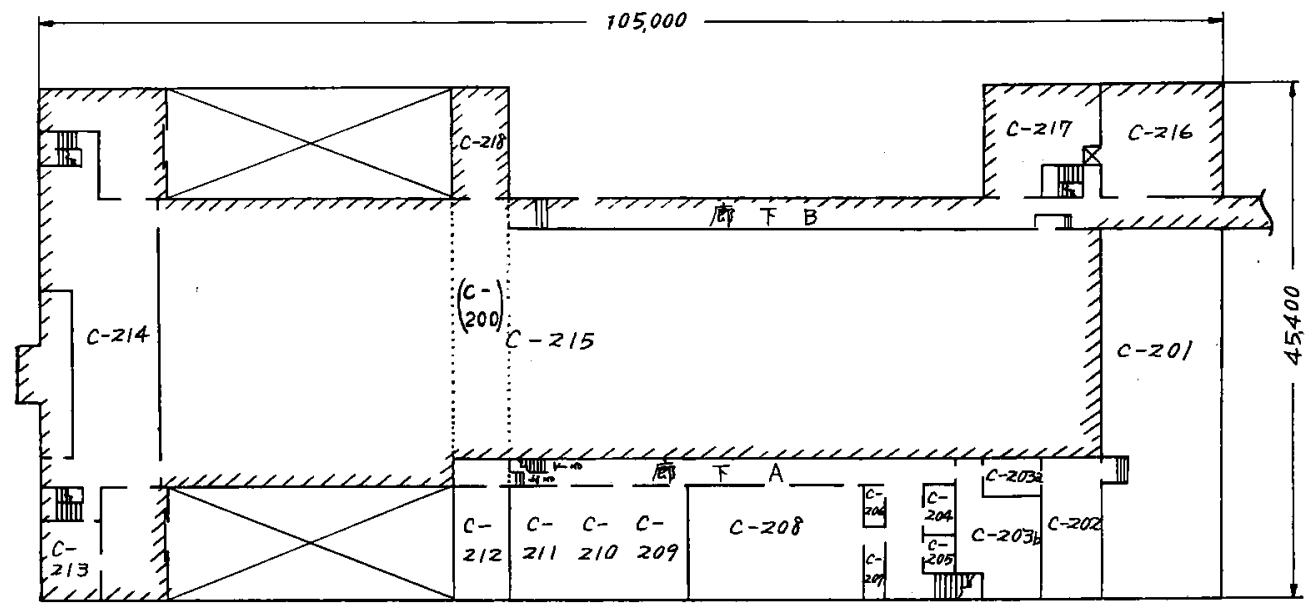
C-216 洗濯室 C-214 排風機室
$\mathrm{C}-201$ 給気室 C-208 C-211 スタッフ室
C-215 フィルタ室
C-200 管理制御室(中 2 階)

第 2 図 2 階平面図

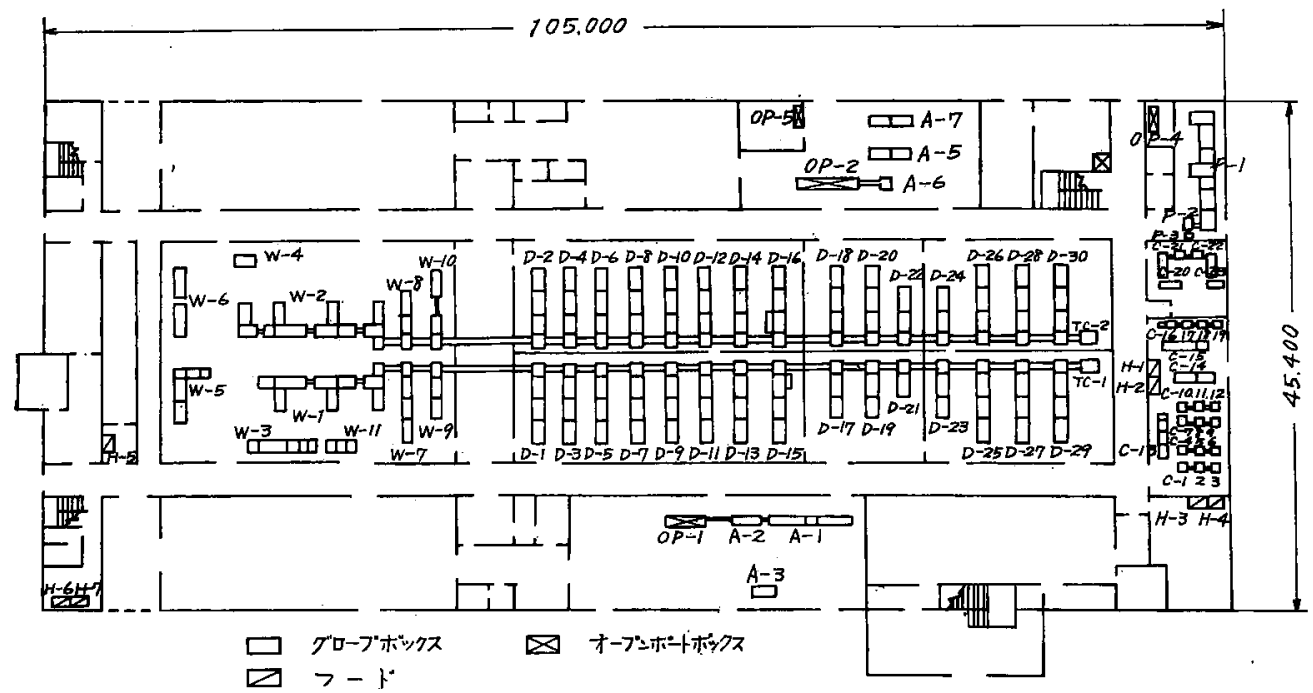

第 3 図 グロブポックス,オープンポートボックス,フード配置図

ルタ，GB 内外の差圧計,消火用チッ素ガス配管等各 種配管, GB 内に温度警報装置等が設備され，作業者が 放射線被曝を受けやすいところには，フクリル樹脂空 板と同形の鉛ガラス空板を GB パネルの上に取り付け てある。写真1,2にこれらGBの状況を示す。

\section{2. 製造工程機器}

Puを大量に取り扱う施設としての建設にあたって は, (1)臨界管理を敩重に実施し，(2)機器は原則として 国産品を用い，(3)操作時間の長い機器の自動化を考 え，(4)放射線被曝の減少を考慮した。この施設運転を
通して将来建設を予想される生産工場施設の設計に奇 与できることを希望している。

$\mathrm{Pu}$ 然料第 2 開発室には, FBR および ATR ラ1 ンの 2 系統の製造施設が設備され，双方に(1)ペレット 製造工程，(2)ペレット充填ピン加工，(3)集合体組立, (4)湿式および乾式回収工程をるっている。これはFBR および ATR 双方の Pu 燃料が同時期に要求されて いることと, 双方間では $\mathrm{Pu}$ の富化度, U漲縮度,ペレ ット径, 被覆管径, 長さ等の差異があり, 同一施設を交 互に使用して同時期の要求を满たさせるようなことが 


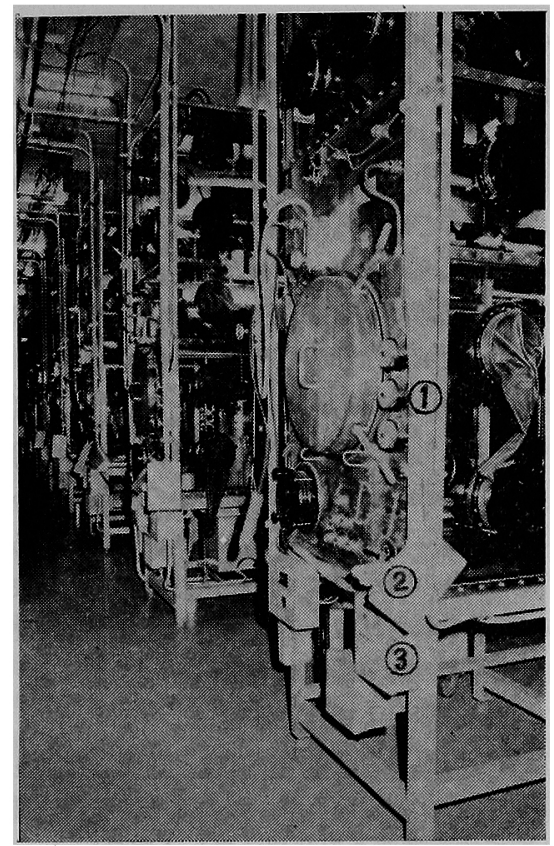

(1) 差圧計，(2) 消火用チッ素ガス配管

(3) 負圧整報装置

写真 1 FBR ラインベレット製造工程のGB

できる性格のるのでないことによる。ちなみに当面 1973年末まで製造が予定されている FBR の「常陽」然 料および ATR の DCA 燃料の仕様概略を第 2 表に示 す。施設として FBR ラインでは混合酸化物ペレット $15 \mathrm{~kg} /$ day, ATR ラインでは $25 \mathrm{~kg} /$ day の製造能力が あり，年間双方で $8 \mathrm{t}$ 程度となる(海外では 現 在 $40 \mathrm{t}$ 級製造施設等を建設中である)。

第 2 表 燃料 仕 様

\begin{tabular}{|c|c|c|}
\hline & JOYO 燃料 & DCA 燃料 \\
\hline 集 合 体 & 91本/体 & 28本/体 \\
\hline 燃 料 棒 & & \\
\hline 被覆管材質 & SUS-32 & Zry. 2 \\
\hline 寸 法 全長 & $1,910 \mathrm{~mm}$ & $2,115 \mathrm{~mm}$ \\
\hline 外径 & $6.3 \mathrm{~mm}$ & $16.68 \mathrm{~mm}$ \\
\hline 内径 & $5.6 \mathrm{~mm}$ & $15.08 \mathrm{~mm}$ \\
\hline 燃料有效長 & $600 \mathrm{~mm}$ & $2,00 \mathrm{~mm}$ \\
\hline 燃料ペレット & & \\
\hline 形 & 真円柱 & 真円柱 \\
\hline 淔 & $5.4 \mathrm{~mm}$ & $14.8 \mathrm{~mm}$ \\
\hline 長 & $10 \mathrm{~mm}$ & $20 \mathrm{~mm}$ \\
\hline 密度 & 9.53T.D. & 94.0 T.D. \\
\hline $\mathrm{Pu}$ 富 化 度 & $18 \%$ & $0.54 \%, 0.87 \%$ \\
\hline${ }^{235} \mathrm{U}$ & $23 \%$ & 天 然 \\
\hline
\end{tabular}

ペレット製造装置として粉末調整装置, ボールミル， グラニュレータ,プレス, 焼結, 径選別装置, 研削, 脱ガ ス, 検查装置と一連の装置を使用するが, 本施設では成 形後の工程はかなり自動化してある。またピンへのぺ レット充嫔とそれに伴らスタック長, 重量の測定を一 連自動化してめり，その後の工程も一部自動化して手 作業を減らして市る(写真 2 )。

回収工程は，溶解イオン交換沈殿精製をたは溶媒抽 出分離, 溶液濃縮装置等から出来ている。

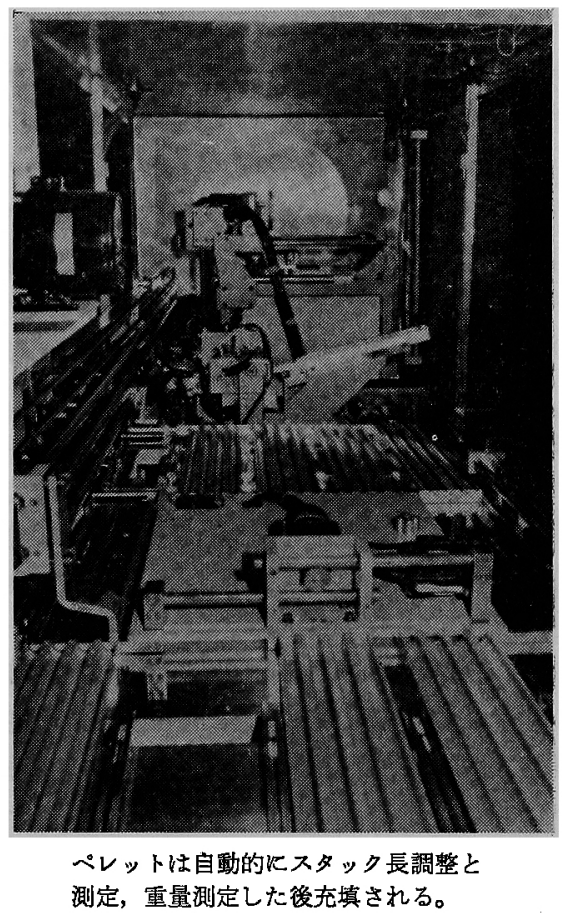

写真 2 ATRラインのペレット充填装置

\section{3. 運転管理設備}

給電設備, 給排気設備, 架調管理, 負圧管理, 各種警報 設備等の自動運転,管理, 保守が集中管理方式下で行わ れている。

\section{（1）給電設備}

買電特高変電設備のほかに停電時約 $30 \mathrm{sec}$ 内に自家 発電機による送電が可能なよらに設備されて和り，自 家発電機も500kW のものが万一事故の埸合は他の 200 $\mathrm{kW}$ ののが稼動するよう2 台設䚚されている。また 雷雨時のよらに電圧の変動が絽り返点される場合は自 家発電機は自動から手動に切り換えられ買電の代わり に稼動送電するようにして排気系の運転を確保し負圧 を維持できるようになっている。

（2）給排気設備 
上記給電設備により $24 \mathrm{hr}$ 運転が行われるが, 買電停 電時は排気系統の運転が瞬時に再開される。排気系が 停止乙て給気系が運転されることは絶対ない機構にな っており，停電後買電復旧時む排気系がまず運転され この間給気系はロックされており，次治気系が運転 される。GBへの給気ロにはフブソリェートフィルタ が取り付けられて停電時污染空気が逆行しない上う防 止されている。GB 排気口技よび煙突への排気前にア ブソリュートフィルタが怙の和の付けられており, 清 浄な空気のみが排気される。

給気は室温 $20^{\circ} \sim 23^{\circ} \mathrm{C}$, 湿度 $40 \sim 60 \%$ に維持できるよ う蒸気また泠冷水等の熱源で自動制御されている。こ れは冬期早朝等室温が下がり過ぎると GB のグローブ が硬くなって作業性を妨げると共に，破損等污染また は事故の原因になりやすい問題を与充，なた湿度が高 い場合ラドントロン等による偽の污染現象を起して Pu 検出に妨害を起したりペレット製造に悪影響を 与えるためである。

\section{(3) 負王管理}

建家の管理区域内は空気污染桩大防止の目的で水柱 1〜4mm の 4 段階に負圧管理がなされて括り，建家の 出入は常時口ビーからの 1 個所と限定され，管理区域 《入る場所は 2 重扉で負圧管理されている。ローディ ングドックるいは非常虔を開ける場合は事前許可を 必要としている。GB 内はさらに負压 $30 \mathrm{~mm}$ 水柱に 24 $\mathrm{hr}$ 維持され，GBの負压管理はクローブ操作の急激な 運動に詨しても充分雓持できるよう，またグローブ破 損あるいは脱落時る污染の桩大を防止するのに充分な 空気の GB への流入が可能なよらに管理されている。

\section{（4）整報施設怙よび管理表示盤}

上記各設備の管理を含めて, 緊急通報施設および管 理表示盤が集中管理化され，警報系が作動吹鳴した場 合, その事故個所を明示するランプが点燈し，非常措 置が即刻とれる体制になっている。設備として下記の むのがある。
(a) 臨界警報
(b) 火災整報
(c) 室内警報
(d) GB温度警報 (e) ドフ警報
(f) 給気表示
（g）排気警報 (h) 負圧整報
（j）室内空気污染異状警報
（k）排気中空気污染異状整報
(1) 出退勤管理区域内作業表示盤

(b), (c), (1)以外はすべて自動化されて括り，上記以外 の連絡設備として電話(村外直通, 村内直通, 事業所内 直通, 部内電話), 部内放送施設, ページングシステム,
個人呼出しポケットベルがある清か，所内ホットライ ン,部内ホットラインが設備されている。各䈏報の吹鳴 音, 断続方式は異方, 臨界整報, 火災警報, 室内貔報の 3 種類は建家すべての場所で聴取可能にしてかり，ま た部内放送音とは異った方向から聞えるよう設備され ている。警報機はリセットを人為的に行わない限り吹 鳴を続ける機構となってょり、リセットは現場保安最 高責任者の指示がなければ行われない。

出退管理表示盤は出入口の口ビーおよび管理区域出 入口に押ボタン方式のあのが設置されており，第 1 開 発室, 第 2 開発室双方を含め, 何方かの建家あるいはと の管理区域内に在室しているかどうかを表示するよう に出来て扣り，表示盤は口ビー以外の双方の建家の管 理室に表示のみされている。祭急退避時はそのままて 退避し残留者の有無確認汇も用いる。

\section{4. 臨界管理および計量管理}

本施設での臨界管理については，前記したように万 全を期して行なっているが，このため特殊核物質の取 扱量, 取扱施設機器の形状等は飭しく制限している。本 施設では特殊核然料物質と減速材との比により乾燥 系, 半減速系, 減速系の 3 つ分類し(第 3 表参照)，各 系は燃料組成により臨界管理安全基準量(第 4,5 表䏍 照)を，然料棒および集合体につき同安全基準量を(第 6,7表参照)定めている。機器配置についても機器配列 および立体角法よりみての相互作用防止の管理基準を 第8,9表のように定めて設計した。とくにFBR湿式回 収工程はすべて形状臨界管理方式をとっている。この ように設計，製作，据付けされた施設は監督官庁により 厳重な倹查を受けて安全性を慎重に確認された上で使 用に供された。むた取报いについては定められた安全 作業基準従って作業される。

第 3 表 減速比に上る系の分類

\begin{tabular}{|c|c|c|c|c|}
\hline \multirow{2}{*}{\multicolumn{2}{|c|}{ 系 }} & & \multicolumn{2}{|c|}{$\mathrm{H} / \mathrm{Pu}^{*}\left(\mathrm{Pu}^{*}={ }^{239} \mathrm{Pu}+{ }^{241} \mathrm{Pu}+{ }^{235} \mathrm{U}\right)$} \\
\hline & & & FBR ライン & ATRライン \\
\hline 乾 & & 燥 & $0 \sim 4$ & $0 \sim 100$ \\
\hline 半 & 減 & 速 & $4 \sim 25$ & $100 \sim 250$ \\
\hline 減 & & 速 & 25 以上 & 250 以上 \\
\hline
\end{tabular}

特殊核燃料物質の移動計量管理はすべて電子計算譏 で処理管理され，すべてのGB, 詝蔵施設の装荷量は臨 界管理上安全であることが確認されて初めて定められ た手法により移動が許されている。GB間の移動は中 央管理制御室より遠隔操作する移送トンネルを使用 し，また分析試料等については計量保員の指示による 
第 4 表 FBRライン臨界管理安全基準量

\begin{tabular}{|c|c|c|c|c|c|}
\hline & & & & $\mathrm{Pu}^{*}$ 第 & K同じ) \\
\hline 系 & 項 & $\begin{array}{l}\text { 安全 } \\
\text { 係数 }\end{array}$ & $\left|\begin{array}{l}23.3 \% \\
\text { 澧縮UO } \\
\mathrm{U}_{2}\end{array}\right|$ & $\mathrm{PuO}_{2}$ & $\begin{array}{l}\text { 混 合 } \\
\text { 酸化物 }\end{array}$ \\
\hline 乾 & 質 量 $(\mathrm{kg})$ & 0.43 & $\begin{array}{c}\mathrm{kg}^{235} \mathrm{U} \\
17.5\end{array}$ & $\begin{array}{l}\text { kgPu } \\
4.6\end{array}$ & $\begin{array}{c}\mathrm{kgPu}{ }^{*} \\
9.8\end{array}$ \\
\hline 怗 & 容 積 $(l)$ & 0.75 & 9.4 & 0.97 & 6.7 \\
\hline & 円筒直径 $(\mathrm{mm})$ & 0.85 & 160 & 64 & 143 \\
\hline 系 & 平 板 厚 $(\mathrm{mm})$ & 0.75 & 50 & 15 & 53 \\
\hline 半 & 量 $(\mathrm{kg})$ & 0.43 & $\begin{array}{c}\mathrm{kg}_{4.7}^{235} \mathrm{U} \\
4.7\end{array}$ & $\underset{2.1}{\mathrm{kgPu}}$ & $\begin{array}{c}\mathrm{kgPu}^{*} \\
3.0\end{array}$ \\
\hline 滅 & 積 $(l)$ & 0.75 & 9.7 & 3.9 & 6.6 \\
\hline 速 & 円筒直径 $(\mathrm{mm})$ & 0.85 & 164 & 112 & 143 \\
\hline 系 & 平 板 厚 $(\mathrm{mm})$ & 0.75 & 57 & 33 & 48 \\
\hline 減 & 量 $(\mathrm{kg})$ & 0.43 & $\begin{array}{c}\mathrm{kg}^{235} \mathrm{U} \\
0.7\end{array}$ & $\begin{array}{r}\mathrm{kgPu} \\
0.22\end{array}$ & $\begin{array}{r}\mathbf{k g P u}{ }^{*} \\
0.25\end{array}$ \\
\hline 躶 & 容 積 $(l)$ & 0.75 & 7.8 & 3.8 & 6.5 \\
\hline & 円筒直径 $(\mathrm{mm})$ & 0.85 & 146 & 112 & 143 \\
\hline 系 & 平 板 厚 $(\mathrm{mm})$ & 0.75 & 52 & 33 & 46 \\
\hline
\end{tabular}

第 5 表 ATRライン臨界管理安全基準量

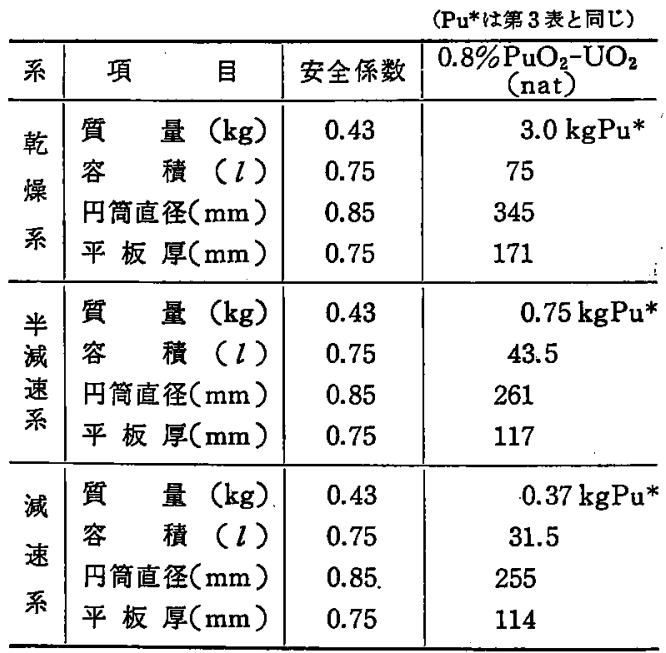

第 6 表 FBR ライン然料棒括よび集合体(91) 本 然料棒)の臨界管理安全基洹量

\begin{tabular}{|c|c|c|}
\hline 条 & $K_{\text {eff }}$ & 安全基準 \\
\hline $\begin{array}{l}\text { 燃料榛最適格子 }(15 \mathrm{~mm} \text { ピッチ) } \\
\text { で水没 }\end{array}$ & 0.9 & 106本 \\
\hline $\begin{array}{l}\text { 燃料桠 } 200 \text { 本( } 2 \text { 日分取扱量)が } \\
\text { 密着 して水没 }\end{array}$ & 0.66 & 200本 \\
\hline 集合体 1 体(91本㘂料棒)が水没 & 0.54 & 1体 \\
\hline
\end{tabular}

ニュマチック移送装置を用いている(写真 3)。

5. 被曝対策

$\mathrm{Pu}$ 取扱いk伴う外部被曝線量は，取扱う Pu量と作
第 7 表 ATRライン燃料棒扰よび集合体(28本 燃料棒)の臨界管理安全基薄量

\begin{tabular}{c|r|r}
\hline 条 & $K_{\text {efP }}$ & 安全基準 \\
\hline 燃料棒最適格子(25mm ピッチ) & 0.9 & 142 本 \\
で水没 \\
集合体1体(28本燃料棒)が水没 & 0.44 & 1 体 \\
\hline
\end{tabular}

第 8 表 機器配列に蛙ける臨界相互 作用防止の管理基準

\begin{tabular}{|c|c|}
\hline ニニット間の最小端面間距離 & $30 \mathrm{~mm}$ \\
\hline $\begin{array}{l}\text { 各ニニット間の最大立体角 } O t \\
(\max ) \text { と制限立体角 } \delta l \text { の関係 }\end{array}$ & $\frac{\Omega t(\max )}{4 \pi}<\Omega l^{\dagger}$ \\
\hline 壁, 床, 天井の中性子反射家考慮 & $\begin{array}{l}\text { Albedo=0.7 } \\
(コ ン ク リ ー ト)\end{array}$ \\
\hline $\begin{array}{l}\text { 必要に応じ中性子スクリーンを } \\
\text { 設置 }\end{array}$ & - \\
\hline
\end{tabular}

第 9 表 立体角法に上る相互作用防止の配置基準

\begin{tabular}{|c|c|c|c|c|c|}
\hline \multirow{2}{*}{ 管 理 室 } & \multicolumn{2}{|c|}{$8 l$} & \multirow{2}{*}{$\begin{array}{l}K_{\text {eff }} \\
(B)\end{array}$} & \multicolumn{2}{|c|}{ 最小隔離条件 } \\
\hline & $\begin{array}{l}\text { ステラ } \\
シ テ テ ン\end{array}$ & 小紋 & & 1 対配置 & $\begin{array}{l}\text { 正方格子 } \\
\text { 配 置 } \\
\end{array}$ \\
\hline 量 & 1.4 & 0.11 & 0.78 & $d / 2 R=0.6$ & $d / 2 R=1.1$ \\
\hline & 1.6 & 0.13 & 0.74 & $d / 2 R=0.5$ & $d / 2 R=1.0$ \\
\hline 円筒直径 & 2.0 & 0.16 & 0.68 & $d / 2 R=0.1$ & $d / 2 R=1.1$ \\
\hline 平 板 厚 & 3.8 & 0.30 & 0.40 & $d / L=0.1$ & \\
\hline
\end{tabular}

$d:$ 端面間卧離 $2 R:$ 球ししくは円筒の直径
$L:$ 正方形平板の辺長

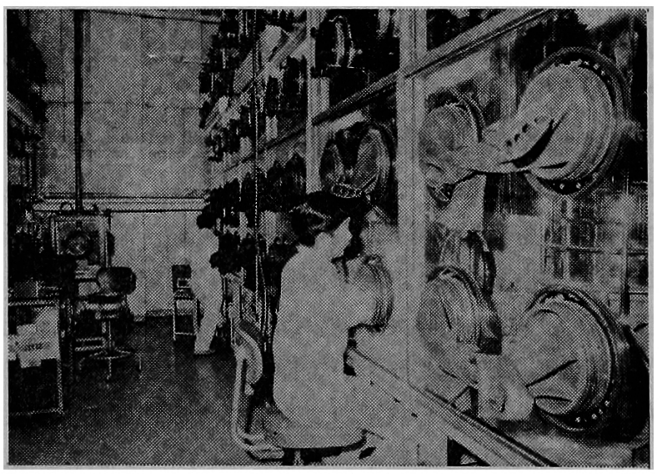

ボックス操作面は鉛ガラスが取り付けてある。左 側の小さいGBはニュマチック移送装置の一部。

军真 3 FBRライン造粒用 GB

業内容, 時間のほか Pu 同位体組成に関係する。1966年 当初動然事業団で取り扱っていた Puは fissile 92\%程 度のものであったが, JOYO 燃料では fissile 82\%程 度, DCA 然料で $80 \%$ 程度のるのが取り扱われ， 線被 
第 10 表 燃料製造スケシュール

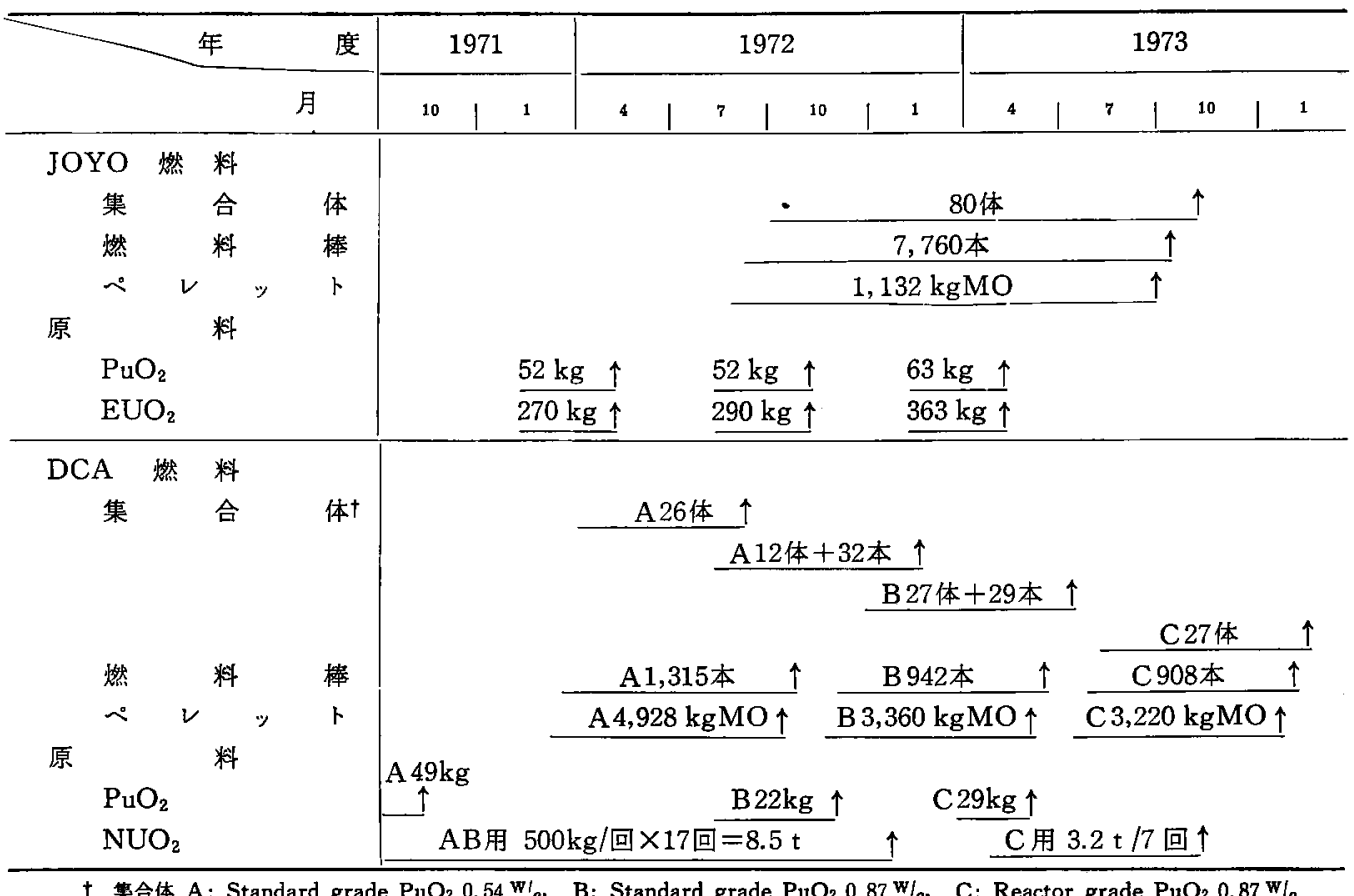

曝およぴ中性子の被曝を考虑する必要がある。 14〜875 keVのうち100 keV以下のものがほとんどで, 最む強いのは $\mathrm{Pu}$ より生ずる ${ }^{241} \mathrm{Am}$ の $60 \mathrm{keV}$ である。 したがって，被曝量を管理する前提条件として取り扱 5 Puの仕様決定に留意する必要があり, 今回 JOYO然 料用のるのの仕様では ${ }^{241} \mathrm{Am}$ は1,000 ppm 以下とし 同じ fissile $82 \%$ $\%$ のでる ${ }^{241} \mathrm{Pu}$ の少ないものとし た。

一定期間の作業者の被嚗線量は，1週間100 mrem, 3 カ月 $1.3 \mathrm{mrem}, 1$ 年 3 rem を越えないよ5管理し ているが, 作業時 GB内で不必要に Pu を一時保管する ことは空間線量率の上昇原因となるので原則的に禁止 しており，やむを得ない場合は鉛板等で線源遮蔽を行 う。操業むGBにはりついて作業する時間は短縮する 方向で考宎，装置も前記のよらにできる範聿で自動化 している。ここで注意すべきことはGB内の整理整頓, ポックス内面のパネルの表面污染が直接被曝に関係し て扣り,操業当初は差異が少ないが，2 年目以降急激に その影響が現われる。海外でもこの点は指摘されて括 り Good House Keeping が提唱されているところで
あり,ステンレス鋼の場合, 内面のポリシィンクの効果 が 2 年後に明示されている。当施設では内面清掃を常 時指示している。遮蔽材としてはさらに鉛 $2 \mathrm{~mm}$ 厚さ 相当量の鉛ガラスを GB パネル表面に重ねて装備させ ているのる前記と拈りである。

\section{III. 現状と今後の計画}

FBR ラインのペレット製造工程特よび回収工程(廃 液処理を含む)の各機器の据付試運転検査はすべて 終 え，1971年 7 月末より天然Uを使用しての試験操業に 入っている。この操業を通じて，設置された機器の特 性把握, 操業性,操業時の必要人員, 連続作業上の問題 点, 計量管理方式の解析等多くの成果を得ている。ま た $\mathrm{Pu}$ 然料本格操業に備えて機器手直し作業を行なっ ている。FBRライン加工組立工程(貯蔵施設を含め), ATR ライン颙式工程組立工程の機器据付む順調に進 み，1972年 2 月当初からの全面 $\mathrm{Pu}$ 取扱操業に万全の 準備体制を整点ている。同時期以降の燃料製造計画は 第10表に示すと扣りで，今後の実績成果を大いに期待 している。 